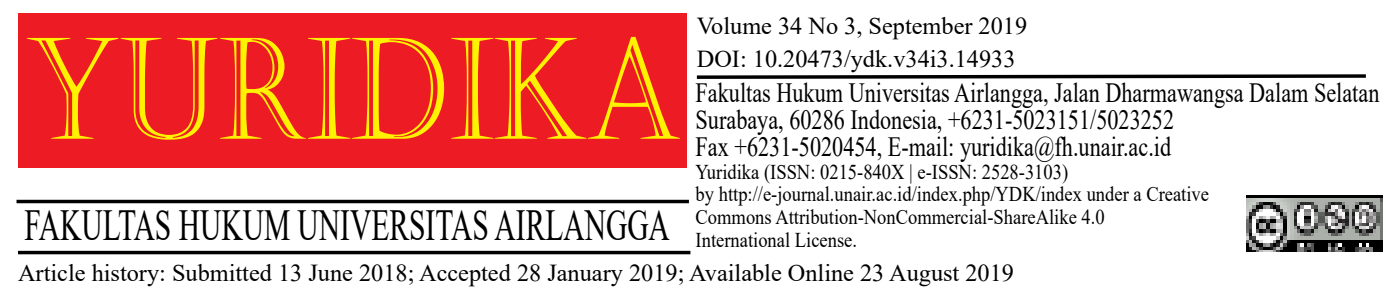

\title{
When Mother Earth Begged for Research: An Indexation of Social and Environmental Hotspots
}

\author{
Tineke Elisabeth Lambooy, Bart Jansen and Martine Bosman* \\ T.Lambooy@nyenrode.nl \\ Nyenrode Business Universiteit
}

\begin{abstract}
This editorial paper is an introduction to the special Yuridika edition about the 'Sustainable Market Actors for Responsible Trade' project (SMART). SMART identifies the areas in which companies and other market players can realise their unfulfilled potential to contribute in their own way to development friendly, environmentally friendly, and socially sustainable business, trade, and investment. SMART creates more awareness on how nondevelopment policies and regulations reinforce or undermine EU development policies. The research presented in this special Yuridika edition aims to find these legal means to reduce the gap between law and reality. In this Editorial, the various contributions to this special edition of the journal Yuridika will be introduced.
\end{abstract}

Keywords: Yuridika; SMART; EU Development Policies.

"Make friends with a few animals". ${ }^{1}$

Global economic development is a worldwide phenomenon that brings enormous benefits and opportunities. At the same time, we mortals and Mother Earth have to deal with the consequences of climate change and the global loss of natural biotopes. This misery is crying out, is begging for scientific research that can contribute to making this economic development more sustainable, within a

* Prof. Dr. T.E. Lambooy LL.M. is Professor of Corporate Law at Nyenrode Business University, Adjunct Professor at UNAIR (Surabaya) and conducts multidisciplinary research projects aimed at the implementation of sustainability goals by private companies. Mr B. Jansen LL.M. is jurist, philosopher, $\mathrm{PhD}$ student at Nyenrode Business University and lecturer sociology and philosophy of law at Leiden University and University of Amsterdam and Guest Lecturer at UNAIR. Mrs M. Bosman LL.M. is PhD student and lecturer business law at Nyenrode Business University. All authors are members of the project team of Sustainable Market Actors for Responsible Trade (SMART) (smart.uio.nl). SMART receives funding from the European Union's Horizon 2020 Research and Innovation Programme under Grant Agreement No 693642, and we gratefully acknowledge its support.

1 Quote from Albert Einstein, vid.: H. Dukas \& B. Hoffmann (eds.), Albert Einstein, The Human Side: Glimpses from His Archives (Princeton University Press 2013).[115]. 
circular economy without emissions that is compatible with the planetary boundaries by international development goals. This special edition of the legal journal Yuridika is completely dedicated to the research results of such scientific research. The SMART project, Sustainable Market Actors for Responsible Trade, conducts research about market actors that serve to promote global, sustainable development. The SMART team responds to a European Union's (EU) call for a better Policy Coherence for Development (PCD), with the emphasis that development must be sustainable - socially, ecologically, and economically. SMART identifies the areas in which companies and other market players can realise their unfulfilled potential to contribute in their own way to development friendly, environmentally friendly, and socially sustainable business, trade, and investment: "Sustainable development is development that meets the needs of the present while safeguarding Earth's lifesupport system on which the welfare of current and future generations depend". 2

SMART creates more awareness on how non-development policies and regulations reinforce or undermine EU development policies. Additionally, SMART analyses the complexity of the regulations within which European market players operate, both the private sector and the public sector in its many market roles. The focus of the study is on international supply chains of products sold in Europe, such as a white T-shirt and jeans. Surprisingly, this special edition of Yuridika is incidentally also devoted to the international supply chains of a white T-shirt and jeans. Nearly all contributors in this edition did research into various social and environmental hotspots in the textile industry of their country. They presented the results of their studies at the SMART conference at the Airlangga Universitas in Surabaya, Indonesia in November 2017 and were invited to contribute to this special edition of Yuridika. ${ }^{3}$ Applying the legal sociological theory of the American legal scholar Lawrence Lessig, SMART conference participants brainstormed together

\footnotetext{
2 www.smart.uio.nl.

3 Stakeholders' Meeting Report, Academic stakeholders' meeting EU SMART Research Project Work Package 3, "Thresholds and Fast Lanes on the Road Towards a More Sustainable Garment Industry”, 16 November 2017, Surabaya, Indonesia, to be published (2019).
} 
about the identified hotspots and the underlying causes. They presented firstly the identified sustainability hotspots in their countries; secondly, the legislation pertinent to such hotspots; and thirdly, considering the causes of the hotspots, possible avenues to address the hotspots and provide solutions - regulatory or non-regulatory solutions. The research presented in this special Yuridika edition aims to find these legal means to reduce the gap between law and reality. In this Editorial, the various contributions to this special edition of the journal Yuridika will be introduced, which have all been double-blind peer reviewed. To clarify the

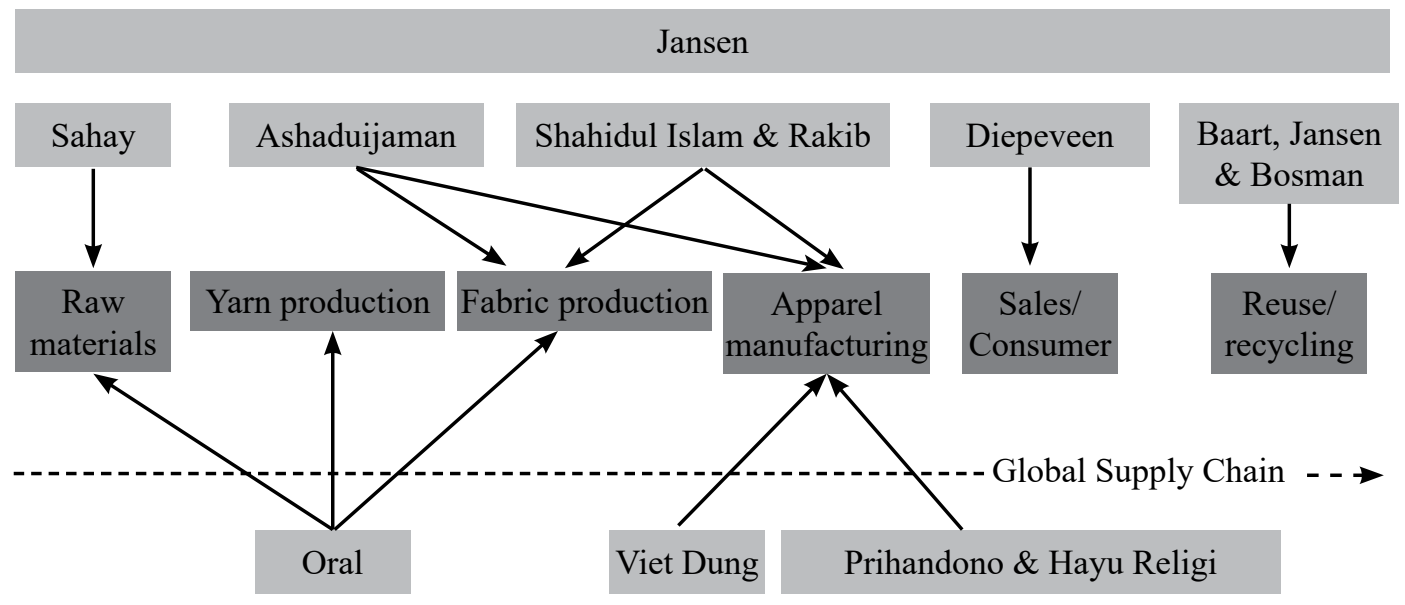

Fig. 1: Structure.

The first contribution comes from Bart Jansen (the Netherlands): 'Towards a Hermeneutics of Pathetic Dots'. Jansen outlines the methodology of the brainstorm session concerning the findings of the various studies presented in this edition. The central questions at the conference in November 2017 focused on how the behaviour of producers of cotton, fabric, and ready-made garments, can be changed in favour of environmental and social sustainability. Jansen provides an interpretation of the Pathetic Dot Theory, designed by Lessig, who assigns an important role to law. In this contribution Jansen presents an approach that can be used to find out in which ways legal means can be applied to achieve an ideal relationship between men and nature.

The second contribution is from Arun Sahay (India): 'Cotton Plantations in India: The Environmental and Social Challenges'. Cotton is one of the principal cash crops of India. It contributes significantly to the country's economy and 
foreign exchange earnings. Approximately 60 million people depend upon cotton production and related industries for their livelihoods. India has the largest cotton plantation area but in terms of yield it falls far behind several other cotton producing countries. Even though cotton occupies only five per cent of India's total cultivable land, approximately 50 per cent of pesticides used in India are consumed by cotton cultivation causing environmental pollution and health hazard. The use of nitrogenbased fertilisers adds to the problem. Many social issues such as child labour, women labour, small land holdings, and unviable livelihoods are also associated with cotton plantations. In recent days, because of the norms set by textile importing countries, these issues have assumed great importance. This contribution of Arun Sahay, after giving a brief introduction of the cotton plantation sector in India, deals with the environmental and social challenges and presents applicable laws in India.

Another cotton producing country is Turkey. This country also faces environmental and social challenges in the cotton production sector. However, with the exception of certain legal loopholes, Turkish labour law and the relevant legislation on environmental protection have largely been harmonised with EU standards. Therefore, the main problems seem to be due to the loose enforcement of these laws due to the shortcomings of the legal system in general. Other reasons that appear to be challenging for effective implementation and enforcement of laws are firstly social realities and secondly, economic constraints and structural obstacles, all of which are being investigated in the study 'Sustainability Challenges of Fast Fashion: Environmental and Social Impacts of Cotton Growing and the ReadyMade Garment Industry in Turkey' by Elif Oral (Turkey) with regard to cotton cultivation and the fabric production industry. The purpose of the study 'Labour Laws in the Garment Sector of Bangladesh: A Workers' View' by Mohammad Shahidul Islam and Abdur Rakib (Bangladesh) is to investigate labour law practices in the garment sector in Bangladesh. With a questionnaire, survey data was collected from companies and workers. The researchers concluded that in many cases the employment law situation was in order (i.e. employment conditions, maternity allowance, working hours and leave), but that in some cases improvement is needed 
(i.e. trade unions, profit participation, and the health of employees).

The 2013 Savar building collapse, also known as the Rana Plaza collapse, prompted various initiatives to be launched all aimed at preventing such accidents in the future. The proposals developed by the initiatives vary from rehabilitation, adjustment of labour law, and implementing conventions for factory inspection, etc. These changes are to be guaranteed by national and international compliance institutions. Apart from these agencies, the majority of the international brands has set their own self-regulation standards for sustainability to ensure a better working environment in fabric and garment production sites in Bangladesh and other RMG producing countries, although, these local and international compliance initiatives have brought significant changes in the work environment in the sector involved. They also posed a number of major challenges for the local manufacturing sector, e.g. to comply with different codes of conduct of so many compliance agencies. In the study 'International Sustainability Self-Regulatory CSR Certification Standards and the Challenges of Embedding Them in the RMG Production Processes in Bangladesh', Ashadujjaman (Bangladesh) presents the most common practices of different codes of conduct in the RMG sector in Bangladesh, with reference to various standardisation organisations and the challenges to embed them in the RMG production processes in Bangladesh. He also indicates that the additional costs with which the local producers are burdened in order to comply with the multiple CSR standards of Western brands are not always or fully translated into a higher price for the RMG products.

The next article is authored by Iman Prihandono and Fajri Hayu Religi (Indonesia): 'Business and Human Rights Concerns in the Indonesian Textile Industry'. The authors discuss business and human rights concerns in the Indonesian textile industry. They elaborate on several cases in which severe environmental damage was caused by the textile industry. They also describe and analyse the human rights standards and policies that have been adopted by international fashion brands. Finally, they underline the importance of the implementation of international standards (i.e. Eco Label and Bangladesh Accord) in Indonesia. 
An important player in the role of economic growth in Vietnam is the Foreign Direct Investment (FDI). In order to attract FDI, the government has committed to encourage an attractive investment climate. FDI, however, also contributes to various environmental problems. In the period of 2008 to 2017, most companies were engaged in production activities that (in)directly polluted the environment. The sanctions imposed by the Vietnam authorities on FDI enterprises may, however, jeopardise the state's responsibilities under investment protection treaties. One of the few realistic approaches to strengthen the environmental management of FDI is to promote the participation of the public in the process of environmental risk assessment and to amend the international investment treaties to regulate the issue of environment management. The study 'Enhancing the Environmental Impact Assessment for the Foreign Direct Investment Regime in Vietnam: An Analysis from Integration Perspective' by Tran Viet Dung (Vietnam) will adopt an integrative approach in which he proposes to integrate the rules and principles of environmental management into the FDI regime of Vietnam.

The research 'The Legislative Framework on Working Conditions in the Dutch Ready-Made Garment Sector' by Rosalien van 't Foort-Diepeveen (the Netherlands) presents the legal framework of labour law provisions that apply to employers and employees working in the RMG retail sector in the Netherlands. There are no severe SHSs in the Dutch retail sector, but there are some issues. The Dutch legislation is generally of secondary importance for the Dutch fashion brands, because the manufacturing of the garments takes place abroad. Dutch law does not apply to employment or the environment abroad. However, various public and private initiatives have been taken to allow Dutch fashion brands to exert influence on the working conditions and the environment in the RMG production countries. Two of these initiatives are discussed in this contribution.

With the industrialisation and the rise of a predominantly material and consumer-oriented society a fundamental change has taken place. The act of discarding products has become an essential part of the production cycle. In order to keep that cycle running, it is important that we constantly purchase products 
that are competitively priced, to keep up with the latest fashions and then, in order to keep up with the fast turnaround, get rid of them again. We do not throw away our belongings because they have become useless, but because we are presented with something newer that we have to wear, use or eat. Unlike with waste, the worthlessness is already entailed in a product that becomes trash. In the Dutch capitalistic consumer society, things are not made to stand the test of time, but to be replaced by other things within the foreseeable future. They are made to be thrown away, and quite often as quickly as possible, because it is this characteristic that guarantees a new purchase. In the last contribution of this special edition, with the title 'Dutch White Trash: A Phoenix Without Ashes. What Happened to the Emperor's Old Clothes?', Rogier Baart, Bart Jansen and Martine Bosman (the Netherlands) will focus on a white T-shirt. The main questions are: What is the current practice in the Netherlands regarding the disposal, separation, reusing, and recycling of this Dutch white trash and how does the legal framework regulate the matter of RMG waste?

In this way, we thank the researchers from all over the place for their highly valued contributions and we also thank the publishers of Yuridika for the opportunity to publish this special edition under the banner of our SMART-project in Yuridika.

Tineke Lambooy, Bart Jansen \& Martine Bosman The guest editors of this special edition of Yuridika HOW TO CITE: Tineke Elisabeth Lambooy, [et., al.]:When Mother Earth Begged for Research: An Indexation of Social and Environmental Hotspots' (2019) 34 Yuridika. 
--This page is intentionally left blank-- 